\title{
Silicon, acibenzolar-S-methyl and potassium phosphite in the control of brown spot in rice
}

\author{
Kelly Juliane Telles Nascimento, Leonardo Araujo, Renata Sousa Resende, Daniel Augusto Schurt, \\ Washington Luís da Silva, Fabrício de Ávila Rodrigues* \\ Universidade Federal de Viçosa - Departamento de Fitopatologia - Viçosa (MG), Brasil.
}

ABSTRACT: This study investigated the effects of silicon ( $\mathrm{Si}$ ),
acibenzolar-S-methyl (ASM), and potassium phosphite (Phi) on
the potentiation of rice resistance to infection by Bipolaris oryzae.
The treatments included the soil amended with Si (1.25 g of calcium
silicate per $\mathrm{kg}$ of soil), spraying of plants with ASM ( $500 \mathrm{mg} \cdot \mathrm{L}^{-1}$ ),
Phi ( $5 \mathrm{~mL} \cdot \mathrm{L}^{-1}$ ), and distilled water (control) $24 \mathrm{~h}$ before inoculation
with $B$. oryzae. The treatments Si supply and the spraying of ASM and
Phi were effective in reducing the area under brown spot progress
curve and the number of lesions per $\mathrm{cm}^{2}$ of leaf. Polyphenoloxidases

\section{INTRODUCTION}

Rice (Oryza sativa L.) is the second most widely grown cereal crop and the staple food for more than half the world's population (Van Nguyen and Ferrero 2006). Susceptibility to diseases is a major factor that greatly decreases rice quality and yield (Van Nguyen and Ferrero 2006). Among the diseases affecting rice production, brown spot, caused by the fungus Cochliobolus miyabeanus (Ito and Kuribayashi) Drechsler (anamorphic form Bipolaris oryzae (Breda de Haan) Shoemaker), is considered one of the most destructive diseases on rice worldwide (Ou 1985). The typical symptoms of this disease are light reddish-brown lesions on the leaf blades or lesions with a grey centre surrounded by a dark to reddish-brown margin and a bright yellow halo (Ou 1985). These lesions reduce the leaf photosynthetic area and sugar concentration on the infected leaves, which, consequently, contributes to a negative impact on rice yield (Dallagnol et al. 2013). Strategies for brown spot control are limited because commercial cultivars with a high level of resistance are not available to the growers, thus the control of the disease is activity was higher for plants supplied with Si. On plants sprayed with ASM, the activities of polyphenoloxidases, phenylalanine ammonia-lyases, chitinases, and $\beta$-1,3-glucanases increased. The spraying of plants with Phi did not increase the activities of the studied defense enzymes. Taken together, the results of this study indicated that brown spot symptoms can be greatly reduced with the use of $\mathrm{Si}, \mathrm{ASM}$, and Phi.

Key words: Bipolaris oryzae, Oryza sativa, host defense responses, induction of resistance, phenylpropanoids, PR-proteins. mainly dependent on fungicides application (Ou 1985). In this way, finding alternative methods for brown spot management is necessary to avoid the yield losses caused by this disease (Dallagnol et al. 2011; 2013; Rezende et al. 2009). In light of these concerns, the supply of silicon ( $\mathrm{Si}$ ) and the use of inducers of resistance to crops of economical importance, such as rice, are shown as an environmentally friendly choice considering the potential of these products to decrease the intensities of important diseases (Araujo et al. 2008, 2015, 2016; Rios et al. 2014; Rodrigues et al. 2003, 2004, 2005).

The supply of Si reduced the severity of brown spot in rice leaves (Dallagnol et al. 2011, 2013; Rezende et al. 2009). The Si-mediated plant resistance to pathogens has been attributed to an increase in the density of the long and short silicate cells in the leaf epidermis or the existence of a thick silica layer below the cuticle that forms a physical barrier which prevents or slows fungal penetration (Hayasaka et al. 2008; Kim et al. 2002). Furthermore, increases in the concentrations of soluble phenolics, lignin, and phytoalexins, an enhanced activity of defense-related enzymes, and the fast and strong transcription of genes that are related to host defense against pathogens are

*Corresponding author: fabricio@ufv.br

Received: Jul. 3, 2015 - Accepted: Oct. 8, 2015 
the reported biochemical mechanisms that are potentiated by Si in plants infected by pathogens (Guerra et al. 2013; Liang et al. 2005; Rodrigues et al. 2003, 2004, 2005; Tatagiba et al. 2014).

Induced resistance is a physiological state of enhanced defensive capacity of the plants against the attack of pathogens such as fungi, bacteria, viruses, and nematodes, elicited by abiotic and/or biotic stimuli, whereby the plant's basal defenses are induced against subsequent biotic challenges (Knoester et al. 1999; Métraux 2001; Ryals et al. 1994; Vallad and Goodman 2004; Van Loon et al. 2006). Induced resistance has been used in rice for the control of bacterial leaf blight and sheath blight (Babu et al. 2003; Rohilla et al. 2001; Schurt et al. 2013). The classic examples of inducible plant defense are systemic acquired resistance (SAR) and induced systemic resistance (ISR), which differ according to the nature of the elicitor and the host regulatory pathway involved (Knoester et al. 1999; Métraux 2001; Ryals et al. 1994; Vallad and Goodman 2004). In general, SAR is related to the production of pathogenesisrelated proteins (PR-proteins), is induced by abiotic and biotic elicitors, and is salicylic acid-dependent (Knoester et al. 1999; Métraux 2001; Ryals et al. 1994; Vallad and Goodman 2004). In contrast, the ISR is not related to PR-protein accumulation, is induced by biotic elicitors, and is signaled via the hormones ethylene and jasmonic acid (Knoester et al. 1999; Métraux 2001; Ryals et al. 1994; Vallad and Goodman 2004). In this context, some compounds such as the acibenzolar-S-methyl (ASM) and potassium phosphite (Phi) have shown the potential to induce resistance in different plants against pathogens (Araujo et al. 2008, 2015; Babu et al. 2003; Rios et al. 2014; Schurt et al. 2013).

The ASM, an analog of the salicylic acid, is a synthetic molecule capable to activate SAR in annual and perennial crops (Araujo et al. 2015; Babu et al. 2003; Rios et al. 2014; Vallad and Goodman 2004). The ASM can systemically activate resistance to various pathogens in many plant species by enhancing the expression of PR-proteins and increasing the concentration of secondary metabolites (Araujo et al. 2015; Babu et al. 2003; Rios et al. 2014; Vallad and Goodman 2004). In rice, the ASM showed its potential to reduce the severity of sheath blight and bacterial blight caused, respectively, by Rhizoctonia solani and Xanthomonas oryzae pv. oryzae (Babu et al. 2003; Rohilla et al. 2001; Schurt et al. 2013).

The Phi, a salt of phosphorous acid, is a systemically mobile chemical that has been used in the management of diseases caused by different pathogens in many plant species (Araujo et al. 2008, 2010, 2015; Dalio et al. 2014; Eshraghi et al. 2011; Förster et al. 1998; Junqueira et al. 2011; Schurt et al. 2013; Smillie et al. 1989). The Phi products are registered as supplemental soil and foliar fertilizers for annual and perennial crops (Araujo et al. 2008, 2010; Förster et al. 1998; Junqueira et al. 2011; Smillie et al. 1989). The Phi generally acts according to its concentration on the host tissue (Dalio et al. 2014; Eshraghi et al. 2011). When the phosphite concentration is low, it induces the synthesis of host defense enzymes, phytoalexins, and phenolics; when its concentration is high, it inhibits pathogen growth (Dalio et al. 2014; Eshraghi et al. 2011).

The induced synthesis of PR-proteins and secondary metabolites in plants supplied with Si or when exposed to exogenous spray of ASM and Phi has been investigated for many host-parasite interactions (Araujo et al. 2015, 2016; Babu et al. 2003; Guerra et al. 2013; Liang et al. 2005; Rios et al. 2014; Rodrigues et al. 2003, 2004, 2005; Rohilla et al. 2001; Tatagiba et al. 2014). The increase in the activities of peroxidases (POX), polyphenoloxidases (PPO), phenylalanine ammonialyases (PAL), chitinases (CHI), $\beta$-1,3-glucanases (GLU), and lypoxigenases (LOX) is one of the most common and efficient defense mechanism activated after the recognition of a pathogen by its host (Van Loon et al. 2006). High PR-proteins synthesis in plants with induced resistance has often been associated with reduction of diseases symptoms on infected plants (Babu et al. 2003; Rodrigues et al. 2005; Rohilla et al. 2001; Rios et al. 2014; Tatagiba et al. 2014). The synthesis of secondary metabolites in plants also play a pivotal role in the host defense against pathogenic infection because these compounds show antimicrobial activity against various pathogens (Araujo et al. 2015, 2016; Guerra et al. 2013; Liang et al. 2005; Nicholson and Hammerschmidt 1992; Rodrigues et al. 2003).

Considering the importance of brown spot to decrease rice yield and the difficulty to achieve a desiderate level of control, it is urgently needed to search for alternative strategies of control. Therefore, this study investigated the possible effects of $\mathrm{Si}, \mathrm{ASM}$, and Phi on the increase in rice resistance, at the biochemical level, against B. oryzae infection.

\section{MATERIALS AND METHODS Soil material}

A Si-deficient typical Acrustox red-yellow latosol, collected in the "Triângulo Mineiro" savannah region of Brazil (Rezende et al. 2009), with $580 \mathrm{~g} \cdot \mathrm{kg}^{-1}$ of clay; $\mathrm{pH} \mathrm{H}_{2} \mathrm{O}(1: 2.5)=4.93 ; \mathrm{P}$ (Mehlich-1) $=0.4 \mathrm{mg} \cdot \mathrm{dm}^{-3}$; 
$\mathrm{K}\left(\right.$ Mehlich-1) $=3.0 \mathrm{mg} \cdot \mathrm{dm}^{-3} ; \mathrm{Al}^{3+}, \mathrm{Ca}^{2+}, \mathrm{Mg}^{2+}, \mathrm{H}^{+} \mathrm{Al}=0.11,0.05$, 0.08 , and $3.8 \mathrm{cmolc} \cdot \mathrm{dm}^{-3}$, respectively; base saturation $=3.6 \%$; organic matter $=2.03 \mathrm{dag} \cdot \mathrm{kg}^{-1} ; \mathrm{B}, \mathrm{Cu}, \mathrm{Fe}$, and $\mathrm{Mn}=0.20$, $0.15,19.0$, and $1.80 \mathrm{mg}^{-\mathrm{dm}^{-3}}$, respectively; field capacity of $0.26 \mathrm{~kg} \cdot \mathrm{kg}^{-1}$, and density of $1.10 \mathrm{~kg} \cdot \mathrm{dm}^{-3}$, was used in this study. The concentration of available $\mathrm{Si}$ (extraction in $\mathrm{CaCl}_{2}$ ) was $2.3 \mathrm{mg} \cdot \mathrm{dm}^{-3}$.

\section{Plant growth and Si supply}

Rice seeds (cultivar Metica-1) were surface sterilized in $10 \%(\mathrm{v} / \mathrm{v}) \mathrm{NaOCl}$ for $1.5 \mathrm{~min}$, rinsed in sterilized water for $3 \mathrm{~min}$, and sowed at the rate of six seeds per plastic pot (12 $\mathrm{cm}$ in diameter) filled with $1 \mathrm{~kg}$ of air-dried, sieved $(5 \mathrm{~mm})$ soil. Five days after emergence, each pot was thinned to two plants. Wollastonite was used as the Si source [calcium silicate (CS; $\mathrm{CaSiO}_{3}$ ); Vansil, EW-10, Ipiranga Chemical Co., São Paulo, Brazil], and it is composed of $24.2 \% \mathrm{Si}$ and $31 \% \mathrm{Ca}$. The wollastonite was incorporated to soil into each pot in the amount of $1.25 \mathrm{~g} \cdot \mathrm{kg}^{-1}$ of soil ( $0.30 \mathrm{~g}$ of elemental Si per kg of soil) (Rezende et al. 2009). Calcium carbonate (40\% Ca; Sigma-Aldrich, São Paulo, Brazil) was added to the pots of the other treatments (control and inducers) in the amount of $0.97 \mathrm{~g} \cdot \mathrm{kg}^{-1}$ of soil to equilibrate the amount of Ca with the treatment containing wollastonite (Rezende et al. 2009). Plants were watered daily as needed.

\section{Application of the inducers}

The inducers used in this study were ASM $\left(500 \mathrm{mg} \cdot \mathrm{L}^{-1}\right.$; Bion ${ }^{\circledR}$, Syngenta Crop Protection, São Paulo, Brazil) and Phi (5 mL/L; Hortifós $®$ PK - 27\% $\mathrm{P}_{2} \mathrm{O}_{5}$ and $27 \% \mathrm{~K}_{2} \mathrm{O}$, Agrichem do Brasil Ltda, Ribeirão Preto, Brazil). Plants sprayed with distilled water served as the control treatment. The plants were sprayed with ASM and Phi separately until runoff using a manual atomizer at $24 \mathrm{~h}$ prior to inoculation with B. oryzae. Plants from the replications of each treatment were maintained in separate compartments during the spraying (once) of the water or the inducers. One hour after being sprayed, the plants were returned to the greenhouse.

\section{Inoculation procedure}

Thirty-day-old plants, at the maximum tillering growth stage, were inoculated with B. oryzae (isolate UFV-Bo 22). Pathogen preservation and inoculum preparation were performed according to Rezende et al. (2009). The isolate of B. oryzae was preserved on filter paper at $-80^{\circ} \mathrm{C}$. Pieces of filter paper containing fungal mycelia were transferred to Petri dishes with potato dextrose agar (PDA) medium. After three days, PDA plugs containing fungal mycelia were transferred to new Petri dishes containing PDA. The Petri dishes were maintained in a growth chamber at $25^{\circ} \mathrm{C}$ with a $12 \mathrm{~h}$ photoperiod for 10 days. After this period, conidia were carefully removed from the Petri dishes using a soft bristle brush and water containing gelatin ( $1 \% \mathrm{wt} / \mathrm{vol})$. The conidial suspension was calibrated using a hemacytometer to obtain a concentration of $5 \times 10^{3}$ conidia por $\mathrm{mL}$. The conidial suspension was sprayed on the adaxial surface of the leaves of each rice plant using a VL Airbrush atomizer (Paasche Airbrush Co., Chicago, USA).

Immediately after inoculation, the plants were transferred to a growth chamber with a temperature of $25 \pm 2{ }^{\circ} \mathrm{C}$, relative humidity of $90 \pm 5 \%$, and were subjected to an initial $24 \mathrm{~h}$ dark period. After this period, the plants were transferred to a plastic mist growth chamber (MGC) inside of a greenhouse for the duration of the experiments. The MGC was constructed of wood ( $2 \mathrm{~m}$ wide, $1.5 \mathrm{~m}$ high, and $5 \mathrm{~m}$ long, covered with $100-\mu \mathrm{m}$-thick transparent plastic). The temperature inside the MGC ranged from $25 \pm 2{ }^{\circ} \mathrm{C}$ (day) to $21 \pm 2{ }^{\circ} \mathrm{C}$ (night). The relative humidity was maintained at $90 \pm 3 \%$ using a misting system (model NEB-100; KGF Company, São Paulo, Brazil), which sprayed mist every $30 \mathrm{~min}$ above the plant canopies. The relative humidity and temperature were measured with a thermohygrograph (TH-508, Impac, São Paulo, Brazil). The maximum natural photon flux density at the plant canopy height was approximately $950 \mu \mathrm{mol} \cdot \mathrm{m}^{-2} \cdot \mathrm{s}^{-1}$.

\section{Disease assessments}

Disease severity was scored at $24,36,48$, and $72 \mathrm{~h}$ after inoculation (hai) on the second, third, and fourth leaves in the main tiller of each plant by using a scale based on the percentage of diseased leaf area (IRRI 1996). Data from disease severity was used to calculate the area under brown spot progress curve (AUBSPC) for each leaf in each plant according to Shaner and Finney (1977). The number of lesions (NL) per $\mathrm{cm}^{2}$ of leaf was counted randomly in three different positions at the central part of the second, third, and fourth leaves in the main tiller of each plant. 


\section{Determination of foliar Si concentration}

After the experiment, leaves of plants from each replication per treatment were collected, washed in deionized water, dried for $72 \mathrm{~h}$ at $65^{\circ} \mathrm{C}$, and grounded in order to pass through a 40 -mesh screen with a Thomas-Wiley mill. The foliar $\mathrm{Si}$ concentration was determined by a colorimetric analysis using $0.1 \mathrm{~g}$ of dried and alkali digested tissue (Korndörfer et al. 2004).

\section{Determination of the activities of POX (EC1.11.1.7), PPO (EC 1.10.3.1), PAL (EC 4.3.1.5), CHI (EC 3.2.1.14), GLU (EC 3.2.1.39) and LOX (EC 1.13.11.12)}

Determinations of the activities of the defense enzymes were performed according to Rios et al. (2014). Leaf samples from one plant per replication of each treatment were collected at $24,36,48$, and 72 hai. The leaf samples were kept in liquid nitrogen $\left(\mathrm{N}_{2}\right)$ during sampling and then stored at $-80^{\circ} \mathrm{C}$ until further analysis. To obtain the extracts used to determine the POX, PPO, PAL, CHI, and GLU activities, a total of $0.2 \mathrm{~g}$ of leaf tissue was macerated with liquid $\mathrm{N}_{2}$ in a mortar with the addition of polyvinylpyrrolidone (PVP) $1 \%(\mathrm{wt} / \mathrm{vol})$ to obtain a fine powder. The powder was homogenized in $2 \mathrm{~mL}$ of $50 \mathrm{mM}$ sodium phosphate (pH 6.5) containing $1 \mathrm{mM}$ phenylmethylsulfonicfluoride (PMSF) and $0.1 \mathrm{mM}$ acid etilenodiaminotetracetic (EDTA). The homogenized material was centrifuged at 20,000 g for $25 \mathrm{~min}$ at $4{ }^{\circ} \mathrm{C}$, and the supernatant was used for enzyme determination.

The POX and PPO activities were determined by the oxidation of pyrogallol according to the method of Kar and Miashra (1976). For POX activity, a mixture of $300 \mu \mathrm{L}$ of distilled water, $250 \mu \mathrm{L}$ of $100 \mathrm{mM}$ potassium phosphate buffer (pH 6.8), $200 \mu \mathrm{L}$ of $100 \mathrm{mM}$ pyrogallol, and $200 \mu \mathrm{L}$ of $100 \mathrm{mM}$ hydrogen peroxide was added to $50 \mu \mathrm{L}$ of the extract. For PPO activity, the mixture was composed of $300 \mu \mathrm{L}$ of distilled water, $250 \mu \mathrm{L}$ of $100 \mathrm{mM}$ potassium phosphate buffer ( $\mathrm{pH} 6.8$ ), and $200 \mu \mathrm{L}$ of $100 \mathrm{mM}$ pyrogallol, which was added to $50 \mu \mathrm{L}$ of the extract. The absorbance was measured in spectrophotometer at $420 \mathrm{~nm}$ every $10 \mathrm{~s}$ for $1 \mathrm{~min}$ after addition of the extract to the mixture in a total of five readings. The molar extinction coefficient of $2.47 \mathrm{mM}^{-1} \cdot \mathrm{m}^{-1}$ was used to calculate POX and PPO activities, which were expressed in mol purpurogallin produced per min.mg of protein.
The PAL activity was determined adding $0.1 \mathrm{~mL}$ of the extract to a mixture containing $0.5 \mathrm{~mL}$ of Tris- $\mathrm{HCl}(\mathrm{pH} 8.8$, $25 \mathrm{mM}$ ) and $0.4 \mathrm{~mL}$ of $100 \mathrm{mML}$-phenylalanine. The reaction mixture was incubated in a water bath at $30^{\circ} \mathrm{C}$ for $3 \mathrm{~h}$. In the control samples, the $L$-phenylalanine was replaced with tris- $\mathrm{HCl}$ buffer. The reaction was finalized by adding $0.1 \mathrm{~mL}$ of $6 \mathrm{~N} \mathrm{HCl}$. The absorbance of the trans-cinnamic acid derivatives was measured in a spectrophotometer at $290 \mathrm{~nm}$, and the molar extinction coefficient of $10^{4} \mathrm{mM}^{-1} \cdot \mathrm{cm}^{-1}$ was used to calculate PAL activity, which was expressed in $\mu \mathrm{mol}$ per min.mg of protein.

The enzyme extracts for $\mathrm{CHI}$ were prepared following the methods of Harman et al. (1993) with a few modifications. The reaction was started by the addition of $20 \mu \mathrm{L}$ of crude enzyme extract to a mixture containing $480 \mu \mathrm{L} 50 \mathrm{mM}$ sodium acetate buffer ( $\mathrm{pH}$ 5.0) and $p$-nitrofenil- $\beta$-D-N$\mathrm{N}^{\prime}$-diacetilquitobiose (Sigma-Aldrich, São Paulo, Brazil) at $2 \mathrm{mg} \cdot \mathrm{mL}^{-1}$. The reaction mixture was incubated in a water bath at $37^{\circ} \mathrm{C}$ for $2 \mathrm{~h}$. Adding $500 \mu \mathrm{L}$ of $0.2 \mathrm{M}$ sodium carbonate terminated the reaction. The absorbance of the end products released by the $\mathrm{CHI}$ present in the crude enzyme extract was recorded at $410 \mathrm{~nm}$. An extinction coefficient of $7 \times 10^{4} \mathrm{mM}^{-1} \cdot \mathrm{cm}^{-1}$ was used to calculate the $\mathrm{CHI}$ activity, which was expressed as mmol of $p$-nitrophenyl per min.mg of protein.

The GLU activity was determined as described by Lever (1972). The reaction was initiated by the addition of $20-\mu \mathrm{L}$ aliquots of the supernatant to a mixture of $230 \mu \mathrm{L}$ of buffer $100 \mathrm{mM}$ sodium acetate (pH 5.0) and $250 \mu \mathrm{L}$ of the substrate laminarin (Sigma-Aldrich, São Paulo, Brazil) in a concentration of $4 \mathrm{mg} \cdot \mathrm{mL}^{-1}$. The reaction mixture was incubated in a water bath for $30 \mathrm{~min}$ at $45^{\circ} \mathrm{C}$. After the incubation period, the amount of reducing sugars was determined by adding $500 \mu \mathrm{L}$ of dinitrosalicylic acid to the mixture and then incubating the resulting mixture in a water bath for $15 \mathrm{~min}$ at $100^{\circ} \mathrm{C}$. The reaction was interrupted by cooling the samples in an ice bath. In the control samples, the reaction mixture was the same, except that the extract was added after heating the mixture at $100{ }^{\circ} \mathrm{C}$. The absorbance of the product released by GLU was measured at $540 \mathrm{~nm}$, and the activity of GLU was expressed in absorbance units $\mathrm{min}^{-1} \cdot \mathrm{mg}^{-1}$ of protein.

To obtain the extract for enzymatic determination of LOX, a total of $0.2 \mathrm{~g}$ of leaf tissue was macerated with liquid $\mathrm{N}_{2}$ in a mortar to obtain a fine powder. The powder was homogenized in $2 \mathrm{~mL}$ buffer of $20 \mathrm{mM}$ sodium phosphate (pH 6.8) containing Triton-X 1\% (vol/vol) and PVP 1\% (wt/vol). The homogenized material was centrifuged at $15,000 \mathrm{~g}$ 
for $20 \mathrm{~min}$ at $4{ }^{\circ} \mathrm{C}$. The supernatant was used as the extract for the determination of LOX activity. The reaction was started by adding $5 \mu \mathrm{L}$ of the extract to a mixture containing $780 \mu \mathrm{L}$ of buffer $50 \mathrm{mM}$ sodium phosphate ( $\mathrm{pH} 6.5)$ and $15 \mu \mathrm{L}$ of $10 \mathrm{mM}$ sodium linoleate substrate. The LOX activity was determined according to the method described by Axelrod et al. (1981). The absorbance of the product released by LOX was measured in a spectrophotometer at $234 \mathrm{~nm}$. The molar extinction coefficient of $25,000 \mathrm{M}^{-1} \cdot \mathrm{cm}^{-1}$ was used to determine LOX activity, which was expressed as $\mu \mathrm{mol}$ per min.mg of protein.

The protein concentration in each sample was determined according to the method of Bradford (1976).

\section{Experimental design}

The experiment was arranged in a completely randomized design with four treatments and six replications. The treatments corresponded to soil amendment with $\mathrm{Si}$ and the foliar spray of ASM, Phi, and distilled water (control treatment). Each replication corresponded to a plastic pot containing $1 \mathrm{~kg}$ of soil and two plants. The experiment was repeated once. Data were submitted to analysis of variance, and the treatment means were compared using the Tukey's test ( $\mathrm{p} \leq 0.05$ ) in the SAS software (Release 8.02 Level 02M0 for Windows; SAS Institute, Inc. 1989, Cary, NC, USA).

\section{RESULTS \\ Foliar Si concentration}

The foliar Si concentration for plants supplied with Si was significantly higher in comparison with plants sprayed with distilled water, ASM, and Phi (Table 1).

\section{Disease assessments}

The AUBSPC was significantly reduced by 73.4, 34.5, and $10.5 \%$, respectively, for the $\mathrm{Phi}, \mathrm{Si}$, and ASM treatments in comparison with the control treatment (Table 1). There were significant decreases of $86.5,80.9,77.2$, and $71.3 \%$ for the NL per $\mathrm{cm}^{2}$ of leaf at $24,36,48$, and 72 hai, respectively, for the Phi treatment in comparison with the control treatment (Table 1). The NL per $\mathrm{cm}^{2}$ of leaf was reduced by 35.1, 40.7, 37.7 , and $38.0 \%$ at $24,36,48$, and 72 hai, respectively, for the Si treatment in comparison with the control treatment (Table 1). For ASM treatment, the NL per $\mathrm{cm}^{2}$ of leaf decreased by $22.5,15.6$, and $12.4 \%$ at 24,36 , and 48 hai, respectively, compared with the control treatment (Table 1).

\section{Activities of defense enzymes}

POX activity was significantly higher for plants from the control and Si treatments in comparison with the ASM and Phi treatments at 24 and 36 hai (Table 2). There was no significant difference among the treatments for POX activity at 48 hai (Table 2). POX activity was higher for plants of the control treatment in comparison with plants from the other treatments at 72 hai (Table 2).

PPO activity was significantly higher for plants from the control treatment in comparison with plants from the ASM and Phi treatments at 24 hai (Table 3) and for plants from the Si treatment compared with plants from the control and Phi treatments at 36 hai (Table 3). PPO activity was higher for plants from the ASM treatment in comparison with plants from the other treatments at 48 and 72 hai (Table 3).

PAL activity was significantly higher for plants from the Phi treatment in comparison with plants from the Si treatment

Table 1. Foliar silicon concentration, area under brown spot progress curve, and the number of lesions per $\mathrm{cm}^{2}$ of leaf for rice plants grown in soil amended with silicon (+Si) or grown in soil amended with calcium carbonate and sprayed with distilled water (control), acibenzolarS-methyl, and potassium phosphite following inoculation with Bipolaris oryzae.

\begin{tabular}{cccccccc} 
Treatments & Si $\left(\mathbf{d a g} \cdot \mathbf{k g}^{-\mathbf{1}}\right)$ & AUBSPC & \multicolumn{3}{c|}{ NL } \\
\cline { 5 - 8 } & & & $\mathbf{2 4}$ hai & $\mathbf{3 6}$ hai & $\mathbf{4 8}$ hai & $\mathbf{7 2}$ hai \\
\hline Control & $1.50 \mathrm{~b}$ & $370.50 \mathrm{a}$ & $25.38 \mathrm{a}$ & $32.28 \mathrm{a}$ & $32.98 \mathrm{a}$ & $34.34 \mathrm{a}$ \\
\hline$+\mathrm{Si}$ & $2.28 \mathrm{a}$ & $242.50 \mathrm{c}$ & $16.47 \mathrm{~b}$ & $19.13 \mathrm{c}$ & $20.55 \mathrm{c}$ & $21.30 \mathrm{~b}$ \\
\hline $\mathrm{ASM}$ & $1.75 \mathrm{~b}$ & $331.50 \mathrm{~b}$ & $19.67 \mathrm{~b}$ & $27.25 \mathrm{~b}$ & $28.88 \mathrm{~b}$ & $31.40 \mathrm{a}$ \\
\hline $\mathrm{Phi}$ & $1.63 \mathrm{~b}$ & $98.50 \mathrm{~d}$ & $3.43 \mathrm{c}$ & $6.18 \mathrm{~d}$ & $7.53 \mathrm{~d}$ & $9.85 \mathrm{c}$ \\
\hline CV (\%) & $\mathbf{8 . 9 8}$ & $\mathbf{9 . 9 8}$ & $\mathbf{1 3 . 9 4}$ & $\mathbf{7 . 3 8}$ & $\mathbf{5 . 9 4}$ & $\mathbf{8 . 6 2}$ \\
\hline
\end{tabular}

Means within each column followed by the same letter are not significantly different $(p=0.05)$ as determined by Tukey's test. Si = Foliar silicon concentration; AUBSPC = Area under brown spot progress curve; $\mathrm{NL}=$ Number of lesions; hai = Hours after inoculation; $\mathrm{ASM}=$ acibenzolar-S-methyl; $\mathrm{Phi}=$ potassium phosphite; $\mathrm{CV}=$ Coefficient of variation. 
at 24 hai (Table 4) and for plants from the control, ASM, and Si treatments compared with plants from the Phi treatment at 36 hai (Table 4). PAL activity was higher for plants from the control treatment in comparison with plants from the ASM and Phi treatments at 48 hai (Table 4) and for plants

Table 2. Activity of peroxidases (mmol per min $\mathrm{mg}$ of protein) on the leaves of rice plants grown in soil amended with silicon (+Si) or grown in soil amended with calcium carbonate and sprayed with distilled water (control), acibenzolar-S-methyl, and potassium phosphite following inoculation with Bipolaris oryzae.

\begin{tabular}{|c|cccc}
\hline Treatments & 24 hai & 36 hai & 48 hai & 72 hai \\
\hline Control & $21.3 \mathrm{a}$ & $23.3 \mathrm{a}$ & $21.0 \mathrm{a}$ & $35.1 \mathrm{a}$ \\
\hline +Si & $21.4 \mathrm{a}$ & $20.9 \mathrm{ab}$ & $20.2 \mathrm{a}$ & $23.4 \mathrm{c}$ \\
\hline ASM & $14.0 \mathrm{~b}$ & $19.3 \mathrm{~b}$ & $20.4 \mathrm{a}$ & $30.1 \mathrm{~b}$ \\
\hline Phi & $15.4 \mathrm{~b}$ & $12.5 \mathrm{c}$ & $21.7 \mathrm{a}$ & $21.7 \mathrm{c}$ \\
\hline CV (\%) & $\mathbf{6 . 9}$ & $\mathbf{7 . 6}$ & $\mathbf{8 . 1}$ & $\mathbf{5 . 6}$ \\
\hline
\end{tabular}

Means within each column followed by the same letter are not significantly different $(p=0.05)$ as determined by Tukey's test. hai = Hours after inoculation; $\mathrm{ASM}=$ acibenzolar-S-methyl; $\mathrm{Phi}=$ potassium phosphite; $\mathrm{CV}=$ Coefficient of variation.

Table 3. Activity of polyphenoloxidases (mmol per min $\mathrm{mg}$ of protein) on the leaves of rice plants grown in soil amended with silicon $(+\mathrm{Si})$ or grown in soil amended with calcium carbonate and sprayed with distilled water (control), acibenzolar-S-methyl, and potassium phosphite following inoculation with Bipolaris oryzae.

\begin{tabular}{|c|cccc}
\hline Treatments & 24 hai & 36 hai & 48 hai & 72 hai \\
\hline Control & $1.33 \mathrm{a}$ & $1.15 \mathrm{~b}$ & $1,47 \mathrm{~b}$ & $1,79 \mathrm{~b}$ \\
\hline $\mathbf{+ S i}$ & $1.27 \mathrm{ab}$ & $1.56 \mathrm{a}$ & $1,52 \mathrm{~b}$ & $1,70 \mathrm{~b}$ \\
\hline $\mathbf{A S M}$ & $1.15 \mathrm{bc}$ & $1.37 \mathrm{ab}$ & $1,91 \mathrm{a}$ & $2,79 \mathrm{a}$ \\
\hline Phi & $1.08 \mathrm{c}$ & $1.24 \mathrm{~b}$ & $1,51 \mathrm{~b}$ & $1,49 \mathrm{~b}$ \\
\hline CV (\%) & $\mathbf{5 . 5 3}$ & $\mathbf{7 . 9 1}$ & $\mathbf{9 . 9 3}$ & $\mathbf{8 . 3 6}$ \\
\hline
\end{tabular}

Means within each column followed by the same letter are not significantly different $(p=0.05)$ as determined by Tukey's test. hai = Hours after inoculation; $\mathrm{ASM}=$ acibenzolar-S-methyl; $\mathrm{Phi}=$ potassium phosphite; $\mathrm{CV}=$ Coefficient of variation.

Table 4. Activity of phenylalanine ammonia-lyases ( $\mu \mathrm{mol}$ per min $\cdot \mathrm{mg}$ of protein) on the leaves of rice plants grown in soil amended with silicon (+Si) or grown in soil amended with calcium carbonate and sprayed with distilled water (control), acibenzolar-S-methyl, and potassium phosphite following inoculation with Bipolaris oryzae.

\begin{tabular}{|c|cccc}
\hline Treatments & 24 hai & 36 hai & 48 hai & 72 hai \\
\hline Control & $3.55 \mathrm{ab}$ & $4.09 \mathrm{a}$ & $5.43 \mathrm{a}$ & $3.98 \mathrm{~b}$ \\
\hline $\mathbf{+ S i}$ & $3.28 \mathrm{~b}$ & $4.08 \mathrm{a}$ & $5.17 \mathrm{ab}$ & $3.96 \mathrm{~b}$ \\
\hline ASM & $3.83 \mathrm{ab}$ & $4.31 \mathrm{a}$ & $4.06 \mathrm{c}$ & $5.11 \mathrm{a}$ \\
\hline Phi & $3.92 \mathrm{a}$ & $3.15 \mathrm{~b}$ & $4.53 \mathrm{bc}$ & $3.77 \mathrm{~b}$ \\
\hline CV (\%) & $\mathbf{7 . 2 9}$ & $\mathbf{6 . 9 7}$ & $\mathbf{7 . 1 3}$ & $\mathbf{7 . 4 4}$ \\
\hline
\end{tabular}

Means within each column followed by the same letter are not significantly different $(p=0.05)$ as determined by Tukey's test. hai = Hours after inoculation; $\mathrm{ASM}=$ acibenzolar-S-methyl; $\mathrm{Phi}=$ potassium phosphite; $\mathrm{CV}=$ Coefficient of variation. from the ASM treatment compared with plants from the other treatments at 72 hai (Table 4).

$\mathrm{CHI}$ activity was significantly higher for plants from the ASM treatment in comparison with plants from the other treatments at 24 and 48 hai (Table 5). CHI activity was significantly greater for plants from the control treatment in comparison with plants from the other treatments at 36 hai and Si and ASM treatments at 72 hai (Table 5).

GLU activity was significantly greater for plants from the control treatment in comparison with plants from the other treatments at 24 hai and Si treatment at 72 hai (Table 6). GLU activity was significantly higher for plants from the ASM treatment in comparison with plants from the Phi treatment at 36 hai and the control and Phi treatments at 48 hai (Table 6).

LOX activity was higher for plants from the control treatment in comparison with plants from the other treatments at 24 and 36 hai and the Si and Phi treatments at 72 hai (Table 7). LOX activity was significantly greater for plants

Table 5. Activity of chitinases ( $\mathrm{mmol}$ per min $\cdot \mathrm{mg}$ of protein) on leaves of the rice plants grown in soil amended with silicon $(+\mathrm{Si})$ or grown in soil amended with calcium carbonate and sprayed with distilled water (control), acibenzolar-S-methyl, and potassium phosphite following inoculation with Bipolaris oryzae.

\begin{tabular}{|c|cccc}
\hline Treatments & 24 hai & 36 hai & 48 hai & 72 hai \\
\hline Control & $2.08 \mathrm{ab}$ & $3.10 \mathrm{a}$ & $2.06 \mathrm{c}$ & $2.61 \mathrm{a}$ \\
\hline $\mathbf{+ S i}$ & $1.82 \mathrm{~b}$ & $2.02 \mathrm{c}$ & $2.44 \mathrm{~b}$ & $1.97 \mathrm{~b}$ \\
\hline $\mathbf{A S M}$ & $2.18 \mathrm{a}$ & $2.34 \mathrm{~b}$ & $2.88 \mathrm{a}$ & $2.03 \mathrm{~b}$ \\
\hline Phi & $1.36 \mathrm{c}$ & $1.74 \mathrm{~d}$ & $1.99 \mathrm{c}$ & $2.62 \mathrm{a}$ \\
\hline CV (\%) & $\mathbf{7 . 5 9}$ & $\mathbf{5 . 3 3}$ & $\mathbf{5 . 9 8}$ & $\mathbf{8 . 1 7}$ \\
\hline
\end{tabular}

Means within each column followed by the same letter are not significantly different $(p=0.05)$ as determined by Tukey's test. hai = Hours after inoculation; $\mathrm{ASM}=$ acibenzolar-S-methyl; $\mathrm{Phi}=$ potassium phosphite; $\mathrm{CV}=$ Coefficient of variation.

Table 6. Activity of $\beta$-1,3-glucanases (absorbance per min·mg of protein) on the leaves of rice plants grown in soil amended with silicon (+Si) or grown in soil amended with calcium carbonate and sprayed with distilled water (control), acibenzolar-S-methyl, and potassium phosphite following inoculation with Bipolaris oryza.

\begin{tabular}{|c|cccc}
\hline Treatments & 24 hai & 36 hai & 48 hai & 72 hai \\
\hline Control & $0.12 \mathrm{a}$ & $0.14 \mathrm{ab}$ & $0,13 \mathrm{bc}$ & $0.15 \mathrm{a}$ \\
\hline $\mathbf{+ S i}$ & $0.09 \mathrm{~b}$ & $0.14 \mathrm{ab}$ & $0.14 \mathrm{ab}$ & $0.12 \mathrm{~b}$ \\
\hline ASM & $0.09 \mathrm{~b}$ & $0.17 \mathrm{a}$ & $0.15 \mathrm{a}$ & $0.14 \mathrm{ab}$ \\
\hline Phi & $0.09 \mathrm{~b}$ & $0.12 \mathrm{~b}$ & $0.12 \mathrm{c}$ & $0.14 \mathrm{ab}$ \\
\hline CV (\%) & $\mathbf{8 . 1 9}$ & $\mathbf{9 . 1 8}$ & $\mathbf{5 . 6 2}$ & $\mathbf{7 . 3 7}$ \\
\hline
\end{tabular}

Means within each column followed by the same letter are not significantly different $(p=0.05)$ as determined by Tukey's test. hai = Hours after inoculation; $\mathrm{ASM}=$ acibenzolar-S-methyl; $\mathrm{Phi}=$ potassium phosphite; $\mathrm{CV}=$ Coefficient of variation. 
from the control and ASM treatments in comparison with plants from the Si and Phi treatments at 48 hai (Table 7).

Table 7. Activity of lipoxygenases ( $\mu \mathrm{mol}$ per $\mathrm{min} \cdot \mathrm{mg}$ of protein) on the leaves of rice plants grown in soil amended with silicon (+Si) or grown in soil amended with calcium carbonate and sprayed with distilled water (control), acibenzolar-S-methyl, and potassium phosphite following inoculation with Bipolaris oryzae.

\begin{tabular}{|c|cccc}
\hline Treatments & 24 hai & 36 hai & 48 hai & 72 hai \\
\hline Control & $0.31 \mathrm{a}$ & $0.29 \mathrm{a}$ & $0.39 \mathrm{a}$ & $0.35 \mathrm{a}$ \\
\hline $\mathbf{+} \mathbf{S i}$ & $0.16 \mathrm{~b}$ & $0.21 \mathrm{~b}$ & $0.23 \mathrm{~b}$ & $0.28 \mathrm{~b}$ \\
\hline ASM & $0.17 \mathrm{~b}$ & $0.24 \mathrm{~b}$ & $0.37 \mathrm{a}$ & $0.32 \mathrm{ab}$ \\
\hline Phi & $0.15 \mathrm{~b}$ & $0.22 \mathrm{~b}$ & $0.18 \mathrm{c}$ & $0.18 \mathrm{c}$ \\
\hline CV (\%) & $\mathbf{6 . 2 8}$ & $\mathbf{7 . 7 9}$ & $\mathbf{7 . 7 2}$ & $\mathbf{8 . 1 8}$ \\
\hline
\end{tabular}

Means within each column followed by the same letter are not significantly different $(p=0.05)$ as determined by Tukey's test. hai $=$ Hours after inoculation; ASM = acibenzolar-S-methyl; $\mathrm{Phi}=$ potassium phosphite; $\mathrm{CV}=$ Coefficient of variation.

\section{DISCUSSION}

Many studies have investigated the effects of Si (Araujo et al. 2016; Dallagnol et al. 2011; 2013; Hayasaka et al. 2008; Kim et al. 2002; Rodrigues et al. 2003, 2004, 2005; Tatagiba et al. 2014), ASM and Phi (Araujo et al. 2008, 2015; Babu et al. 2003; Rohilla et al. 2001; Schurt et al. 2013) on the reduction of diseases intensity in various plant species. However, regarding the rice- $B$. oryzae interaction, this is the first study, to the best of the authors' knowledge, to present some biochemical evidence regarding the brown spot control using Si, ASM, and Phi.

The supply of Si to rice plants reduced the AUBSPC and the NL per $\mathrm{cm}^{2}$ of leaf without significantly increasing the activities of the studied defense enzymes, except for PPO. The Si-mediated host resistance to plant diseases has been attributed to the potentiation of the phenylpropanoid pathway and/or the formation of a physical barrier below the cuticle (Hayasaka et al. 2008; Kim et al. 2002; Rodrigues et al. 2003, 2004, 2005). The PPO participates in the oxidation of phenolics leading to the production of quinones, which are extremely toxic to many pathogens (Campbell and Sederoff 1996). Guerra et al. (2013) and Liang et al. (2005) reported that $\mathrm{Si}$ potentiated the resistance to ramulosis and powdery mildew in cotton and cucumber, respectively, through an increase in the activities of POX and PPO that stimulated the accumulation of phenolic compounds. Tatagiba et al. (2014) reported that high concentrations of soluble phenolics (SP) and lignin-thioglycolic acid derivatives (LTGA), in association with greater activities of POX, PPO, PAL, and LOX, in the leaves of rice plants supplied with $\mathrm{Si}$, contributed to reduce leaf scald severity. Whereas, Silva et al. (2012) reported that the reduction on brown spot severity was not associated with the increase in POX, PPO, and PAL activities, although it was linked with higher concentrations of SP and LTGA on rice plants supplied with Si (Dallagnol et al. 2011). Araujo et al. (2016) showed that in the leaf cells of rice plants supplied with Si, the plant cell walls and the hyphae of Microdochium oryzae were protected and surrounded, respectively, by phenolic-like compounds. Therefore, the reduced levels of brown spot on the leaves of rice plants supplied with $\mathrm{Si}$ were most likely due to an increase in the activities of PPO that incited the production of phenolic compounds. Furthermore, high Si concentration in the leaves may have contributed to the formation of a physical barrier that hampered B. oryzae penetration and further leaf tissue colonization of rice plants supplied with Si.

The AUBSPC and the NL per $\mathrm{cm}^{2}$ of leaf were also negatively affected in plants sprayed with ASM, which can be explained, at least in part, by the greater activities of PPO, PAL, CHI, and GLU. The PAL catalyzes the desamination of the amino acid $L$-phenylalanine with the formation of trans-cinnamic acid, which is the precursor of several types of phenolics in the phenylpropanoid pathway, with lignin being the final product (Campbell and Sederoff 1996). The CHI and GLU catalyze the hydrolysis of chitin and $\beta$-1,3-glucan, respectively, in the cell wall of many fungi and may also release elicitors of host defense responses (Keen and Yoshikawa 1983). The increase in PPO, PAL, CHI, and GLU activities for plants sprayed with ASM indicated their importance for rice resistance to brown spot even though their activities suffered oscillation during the time course evaluated. According to Steiner and Schönbeck (1995), high and stable synthesis of PR-proteins is dependent on an adequate time interval between the exposure of the plant to a certain inducer and the final expression of the host resistance, the absence of specificity in the protection, and the defense mechanisms which are dependent on the plant genotype. Rohilla et al. (2001) reported that the protection degree of rice against sheath blight and the activity of defense enzymes increased with an increase in the duration between ASM application and plant inoculation with $R$. solani. Babu et al. (2003) investigated the possible defense responses in rice plants sprayed with ASM at 24, 48, and $72 \mathrm{~h}$ before inoculation 
(hbi) with X. oryzae pv. oryzae. Although all preventive treatments with ASM significantly reduced the bacterial leaf blight severity, only the pre-treatment at $72 \mathrm{hbi}$ increased the concentration of phenolics and the accumulation of PR-proteins (Babu et al. 2003). Rice plants from cultivar BR-Irga 409 sprayed with ASM or Phi and inoculated with $R$. solani showed reduced values of relative lesion extension, but these same inducers had no effect on the cultivar Labelle considered to be more resistant to sheath blight (Schurt et al. 2013). In the present study, it is possible to postulate that different time intervals between the inducer treatment and fungal inoculation as well as the use of other rice cultivars could have resulted in greater defense enzyme activities and, consequently, contributed to decrease even more the severity of brown spot on ASM sprayed plants.

The spraying of plants with Phi reduced the AUBSPC and the NL per $\mathrm{cm}^{2}$ of leaf without significantly increasing the activities of the studied defense enzymes. Several studies have reported that Phi can directly inhibit fungal infection in the host tissue or indirectly increase host resistance to different diseases (Araujo et al. 2008, 2010, 2015; Dalio et al. 2014; Eshraghi et al. 2011; Smillie et al. 1989). Araujo et al. $(2008,2010)$ reported that preventive treatment of Phi did not reduce Glomerella leaf spot severity on apple seedlings, but the Phi showed curative effect until 48 hai and affected fungal mycelial growth during the in vitro assays. In opposite, Araujo et al. (2015) observed that preventive spray of mango plants with Phi reduced mango wilt development and induced microscopic defense responses to infection by C. fimbriata such as accumulation of phenolic-like compounds, formation of an antifungal barrier, and quick deposition of tyloses impregnated with phenolics. Furthermore, Phi potentiated the synthesis of the alkaloids theobromine and 7-methylxanthine and of the phenolics catechin, epicatechin, epigallocatechin, gallic acid, myricetin, $p$-coumaric acid, p-hydroxybenzoic acid, phloridzin, sinapinic acid, and salicylhydroxamic acid in the mango stem tissues (Araujo et al. 2015). In present study, the reduction in brown spot severity indicated that the Phi probably acted directly against B. oryzae once this product was inefficient to potentiate the activities of the studied defense enzymes.

\section{CONCLUSION}

The supply of $\mathrm{Si}$ as well as the spraying of ASM and Phi on rice plants contributed to reduce the symptoms of brown spot and possibly can become potential products to control this disease in regions with the occurrence of frequent epidemics.

\section{REFERENCES}

Araujo, L., Bispo, W. M. S., Rios, V. S., Fernandes, S. A. and Rodrigues, F. A. (2015). Induction of the phenylpropanoid pathway by acibenzolar-s-methyl and potassium phosphite increases mango resistance to Ceratocystis fimbriata infection. Plant Disease, 99, 447-459. http://dx.doi.org/10.1094/ PDIS-08-14-0788-RE.

Araujo, L., Borsato, L. C., Valdebenito-Sanhueza, R. M. and Stadnik, M. J. (2008). Fosfito de potássio e ulvana no controle da mancha foliar da gala em macieira. Tropical Plant Pathology, 33, 74-80. http://dx.doi.org/10.1590/S1982-56762008000200009.

Araujo, L., Paschoalino, R. S. and Rodrigues, F. A. (2016). Microscopic aspects of silicon-mediated rice resistance to leaf scald. Phytopathology. http://dx.doi.org/10.1094/PHYTO-04-15-0109-R.

Araujo, L., Valdebenito-Sanhueza, R. M. and Stadnik, M. J. (2010). Avaliação de formulações de fosfito de potássio sobre Colletotrichum gloeosporioides in vitro e no controle pós-infeccional da mancha foliar de Glomerella em macieira. Tropical Plant Pathology, 35, 54-59. http://dx.doi.org/10.1590/S1982-56762010000100010.

Axelrod, B., Cheesbrough, T.M. and Laasko, S. (1981). Lipoxygenases from soybeans. Methods in Enzymology, 71, 441-451.

Babu, R. M., Sajeena, A., Samundeeswari, A. V., Sreedhar, A., Vidhyasekeran, P. and Reddy, M. S. (2003). Induction of bacterial blight (Xanthomonas oryzae pv. oryzae) resistance in rice by treatment with acibenzolar-S-methyl. Annals of Applied Biology, 143, 333-340. http://dx.doi.org/10.1111/j.1744-7348.2003. tb00302.x.

Bradford, M. N. (1976). A rapid and sensitive method for the quantitation of microgram quantities of protein utilizing the principle of protein-dye binding. Analytical Biochemistry, 72, 248-254. http:// dx.doi.org/10.1016/0003-2697(76)90527-3. 
Campbell, M. M. and Sederoff, R. R. (1996). Variation in lignin contend and composition. Plant Physiology, 110, 3-13. http:// dx.doi.org/10.1104/pp.110.1.3.

Dalio, R. J. D., Fleischmann, F., Humez, M. and Osswald, W. (2014). Phosphite protects Fagus sylvatica seedlings towards Phytophthora plurivora via local toxicity, priming and facilitation of pathogen recognition. PLoS One, 9, e87860. http://dx.doi.org/10.1371/ journal.pone.0087860.

Dallagnol, L. J., Rodrigues, F. A., Chaves, A. R. M., Vale, F. X. R. and DaMatta, F. M. (2013). Photosynthesis and sugar concentration are impaired by the defective active silicon uptake in rice plants infected with Bipolaris oryzae. Plant Pathology, 62, 120-129. http:// dx.doi.org/10.1111/j.1365-3059.2012.02606.x.

Dallagnol, L. J., Rodrigues, F. A., DaMatta, F. M., Mielli M. V. B. and Pereira, S. C. (2011). Deficiency in silicon uptake affects cytological, physiological, and biochemical events in the rice-Bipolaris oryzae interaction. Phytopathology, 101, 92-104. http://dx.doi.org/10.1094/ PHYTO-04-10-0105.

Eshraghi, L., Anderson, J., Aryamanesh, N., Shearer, B., McComb, J., Hardy, G. E. S. J. and O'Brien, P. A. (2011). Phosphite primed defence responses and enhanced expression of defence genes in Arabidopsis thaliana infected with Phytophthora cinnamomi. Plant Pathology, 60,1086-1095. http://dx.doi.org/10.1111/j.1365-3059.2011.02471.x.

Förster, H., Adaskaveg, J. E., Kim, D. H. and Stanghellini, M. E. (1998). Effect of phosphite on tomato and pepper plants and on susceptibility of pepper to Phytophthora root and crown rot in hydroponic culture. Plant Disease, 82, 1165-1170. http://dx.doi. org/10.1094/PDIS.1998.82.10.1165.

Guerra, A. M. N. M., Rodrigues, F. A., Berger, P. G., Barros, A. F., Silva, Y. C. R. and Lima, T. C. (2013). Aspectos bioquímicos da resistência do algodoeiro à ramulose potencializada pelo silício. Bragantia, 72, 292-303. http://dx.doi.org/10.1590/brag.2013.036.

Harman, G. E., Hayes, C. K., Lorito, M., Broadway, R. M., Di Pietro, A., Peterbauer, C. and Tronsmo, A. (1993). Chitinolytic enzymes of Trichoderma harzianum, purification of chitobiosidase and endochitinase. Phytopathology, 83, 313-318. http://dx.doi. org/10.1094/Phyto-83-313.

Hayasaka, T., Fujii, H. and Ishiguro, K. (2008). The role of silicon in preventing appressorial penetration by the rice blast fungus. Phytopathology, 98, 1038-1044. http://dx.doi.org/10.1094/ PHYTO-98-9-1038.
Internationl Rice Research Institute (1996). Standard evaluation system for rice. Los Banos, The Philippines: IRRI.

Junqueira, K. P., Faleiro, F. G., Uesugi, C. H., Junqueira, N. T. V., Bellon, G., Santos, E. C. and Ramos, L. N. (2011). Desempenho agronômico de maracujazeiros tratados com produtos alternativos e fertilizantes foliares. Revista Brasileira de Fruticultura, 33, 40-47. http://dx.doi.org/10.1590/S0100-29452011005000019.

Kar, M. and Miashra, D. (1976). Catalase, peroxidase and polyphenoloxidase activities during rice leaf senescence. Plant Physiology, 57, 315-319. http:/dx.doi.org/10.1104/pp.57.2.315.

Keen, N. T. and Yoshikawa, M. (1983). $\beta$-1,3-endoglucanase from soybean releases elicitor active carbohydrates from fungus cell walls. Plant Physiology, 71, 460-465. http://dx.doi.org/10.1104/ pp.71.3.460.

Kim, S. G., Kim, K. W., Park, E. W. and Choi, D. (2002). Siliconinduced cell wall fortification of rice leaves: a possible cellular mechanism of enhanced host resistance to blast. Phytopathology, 92, 1095-1103. http:/dx.doi.org/10.1094/PHYTO.2002.92.10.1095.

Knoester, M., Pieterse, C. M. J., Bol, J. F. and Van Loon, L. C. (1999). Systemic resistance in Arabidopsis induced by rhizobacteria requires ethylene-dependent signaling at the site of application. Molecular Plant-Microbe Interactions, 12, 720-727. http://dx.doi. org/10.1094/MPMI.1999.12.8.720.

Korndörfer, G. H., Pereira, H. S. and Nola, A. (2004). Análise de silício: solo, planta e fertilizante (Boletim Técnico $N^{\circ} 2$ 2). Uberlândia: Universidade Federal de Uberlândia.

Lever, M. (1972). A new reaction for colorimetric determination of carbohydrates. Analytical Biochemistry, 47, 273-279. http://dx.doi. org/10.1016/0003-2697(72)90301-6.

Liang, Y. C., Sun, W. C., Si, J. and Römheld, V. (2005). Effects of foliar- and root-applied silicon on the enhancement of induced resistance to powdery mildew in Cucumis sativus. Plant Pathology, 54, 678-685. http://dx.doi.org/10.1111/j.1365-3059.2005.01246.x.

Métraux, J. P. (2001). Systemic acquired resistance and salicylic acid: current state of knowledge. European Journal of Plant Pathology, 107, 13-18. http://dx.doi.org/10.1023/A:1008763817367.

Nicholson, R. L. and Hammerschmidt, R. (1992). Phenolic compounds and their role in disease resistance. Annual Review of Phytopathology, 30, 369-389. http://dx.doi.org/10.1146/annurev. py.30.090192.002101. 
Ou, S. H. (1985). Rice diseases (2nd ed.). Kew: Common Wealth Mycological Institute.

Rezende, D. C., Rodrigues, F. A., Carré-Missio, V., Schurt, D. A., Kawamura, I. K. and Korndörfer, G. H. (2009). Effect of root and foliar applications of silicon on brown spot development in rice. Australasian Plant Pathology, 38, 67-73. http://dx.doi.org/10.1071/ AP08080.

Rios, J. A., Rodrigues, F. A., Debona, D., Resende, R. S., Moreira, W. R. and Andrade, C. C. L. (2014). Induction of resistance to Pyricularia oryzae in wheat by acibenzolar-S-methyl, ethylene and jasmonic acid. Tropical Plant Pathology, 39, 224-233. http://dx.doi. org/10.1590/S1982-56762014000300006.

Rodrigues, F. A., Benhamou, N., Datnoff, L. E., Jones, J. B. and Bélanger, R. R. (2003). Ultrastructural and cytochemical aspects of silicon mediated rice blast resistance. Phytopathology, 93, 535546. http://dx.doi.org/10.1094/PHYTO.2003.93.5.535.

Rodrigues, F. A., Jurick II, W. M., Datnoff, L. E., Jones, J. B. and Rollins, J. A. (2005). Silicon influences cytological and molecular events in compatible and incompatible rice-Magnaporthe grisea interactions. Physiological and Molecular Plant Pathology, 66, 144159. http://dx.doi.org/10.1016/j.pmpp.2005.06.002.

Rodrigues, F. A., McNally, D. J., Datnoff, L. E., Jones, J. B., Labbé, C., Benhamou, N., Menzies, J. G. and Bélanger, R. R. (2004). Silicon enhances the accumulation of diterpenoid phytoalexins in rice: a potential mechanism for blast resistance. Phytopathology, 94, 177183. http://dx.doi.org/10.1094/PHYTO.2004.94.2.177.

Rohilla, R., Singh, U. S. and Singh, R. L. (2001). Mode of action of acibenzolar-S-methyl against sheath blight of rice, caused by Rhizoctonia solani Kühn. Pest Management Science, 58, 63-69. http://dx.doi.org/10.1002/ps.423.

Ryals, J., Uknes, S. and Ward, E. (1994). Systemic acquired resistance. Plant Physiology, 104, 1109-1112. http://dx.doi.org/10.1104/ pp.104.4.1109.

Schurt, D. A., Rodrigues, F. A., Carré-Missio, V. and Soares, N. F. F. (2013). Silício alterando compostos derivados da pirólise de bainhas foliares de plantas de arroz infectadas por Rhizoctonia solani. Bragantia, 72, 52-60. http://dx.doi.org/10.1590/ S0006-87052013005000020.

Shaner, G. and Finney, R. E. (1977). The effect of nitrogen fertilization on the expression of slow-mildewing resistance in Knox wheat. Phytopathology, 70, 1183-1186. http:// dx.doi.org/10.1094/ Phyto-67-1051.

Silva, M. R. J., Pereira, S. C., Rodrigues, F. A., Zanão Júnior, L. A., Fontes, R. L. F. and Oliveira, M. G. A. (2012). Silicon and manganese on the activity of enzymes involved in rice resistance against brown spot. Tropical Plant Pathology, 5, 339-345. http://dx.doi.org/10.1590/ S1982-56762012000500006.

Smillie, R., Grant, B. R. and Guest, D. (1989). The mode of action of phosphite: evidence for both direct and indirect modes of action on three Phytophthora spp. in plants. Phytopathology, 79, 921-926. http://dx.doi.org/10.1094/Phyto-79-921.

Steiner, U. and Schönbeck, F. (1995). Induced disease resistance in monocots. In R. Hammerscmidt and J. Kuc (Eds.), Induced resistance to disease in plants (p. 86-110). Dordrecht: Kluwer Academic Publishers.

Tatagiba, S. D., Rodrigues, F. A., Filippi, M. C. C., Silva, G. B. and Silva, L. C. (2014). Physiological responses of rice plants supplied with silicon to Monographella albescens infection. Journal of Phytopathology, 162, 596-606. http://dx.doi.org/10.1111/jph.12231.

Vallad, G. E. and Goodman, R. M. (2004). Systemic acquired resistance and induced systemic resistance in conventional agriculture. Crop Science, 44, 1920-1934. http://dx.doi.org/10.2135/ cropsci2004.1920.

Van Loon, L. C., Rep, M. and Pieterse, C. M. J. (2006). Significance of inducible defense-related proteins in infected plants. Annual Review of Phytopathology, 44, 135-162. http://dx.doi.org/10.1146/ annurev.phyto.44.070505.143425.

Van Nguyen, N. and Ferrero, A. (2006). Meeting the challenges of global rice production. Paddy and Water Environment, 4, 1-9. http://dx.doi.org/10.1007/s10333-005-0031-5. 